\title{
EVALUATION OF ESTROIDOGENIC EFFECT OF GIBBERRELLIC ACID IN AGING HENS
}

\author{
Alaa E. A. Elkomy ${ }^{1}$, O.A. Elghalid ${ }^{2}$ and Samar A. Elnagar ${ }^{2}$ \\ 1- Arid Lands Cultivation Research Institute, City of Scientific Research and Technology \\ Applications, 2- Poultry Production Department., Faculty Of Agriculture, Alexandria University, \\ Alexandria, Egypt
}

\section{SUMMARY}

To study the estroidogenic effect of Gibberrelic acid in aging hens, a total of 100 hens at the end of egg production curve (64 weeks of age) from Alexandria strain were used. Birds were assigned to 5 treatments. Groups 2 and 3 were injected subcutaneously with 200, $400 \mu \mathrm{g}$ Gibberellic acid $\left(G A_{3}\right) / \mathrm{kg}$ body weight/week, while, groups 4 and 5 were injected with the same solution which contains 100 and $200 \mu \mathrm{g}$ estradiol 17- $\beta\left(E_{2}\right) / \mathrm{kg}$ body weight/week, whereas, group 1 served as control. Overall, low and high $E_{2}$ treatments resulted in a 340 and $240 \%$ increase, respectively in LH concentrations whereas, low and high $\mathrm{GA}_{3}$ treatments resulted in a 25 and $185 \%$ increase, respectively. Regarding FSH concentrations, it increased to reach $400 \%$ and $427 \%$ of control for low-and high- $E_{2}$, respectively, low and high $\mathrm{GA}_{3}$ treatments resulted in a 27 and $80 \%$ increase, respectively. GA treatment resulted in a 13 and $50 \%$ increase in $E_{2}$ compared to control with the low and high doses, respectively. Overall,egg production increased as a result of low- and high- $E_{2}$ treatments by $19 \%$ and $9 \%$, respectively, over control. Whereas, it decreased by $9 \%$ with low-GA 3 and didn't differ than control with the high-GA $A_{3}$. Overall, booth $E_{2}$ and $G A_{3}$ treatments showed significant increases in blood calcium level by 17 and $14 \%$ over control due to the low and high- $E_{2}$ treatments and 14 and $13 \%$ over control due to the low and high-GA $\mathrm{A}_{3}$ treatments, respectively. Serum total protein increased as a result of either $E_{2}$ or $G_{3}$ treatments.

It could be concluded that gibberrelic acid exerts effects on aged hens which are partialy similer to estrogen effects mimicing its actions on egg production traits and blood profile. Moreover, estrogen hormone levels suggest that gibberrilc acid can also stimulate estrogen secration.

Keyword: Gibberellic acid, estradiol, egg production, LH and FSH hormones

\section{INTRODUCTION}

Gibberellic acid $\left(\mathrm{GA}_{3}\right)$ is a natural hormone that can be readily extracted from common plants and acts as growth promoter (Riley, 1987). The effect of gibberellic acid on various aspects of plant growth and development has been extensively researched (Riley, 1987; Baydar, 2002; Celik et al., 2007). Because of the possible use of $\mathrm{GA}_{3}$ in spray applications for promoting plant growth in field crops and the presence of potentially high residual levels which can reach $630 \mu \mathrm{g}$. per $\mathrm{lb}$ of plant materials used in poultry feeds, subsequent studies were conducted to elucidate effects of $\mathrm{GA}_{3}$ on birds' performance (Anderson et al., 1982; Abdel-Hamid et al., 1994; Azza et al., 2003; and Elkomy, 2003). On the other hand, $\mathrm{GA}_{3}$ has been reported to have number of endocrine effects (Gawienowski et al., 1977 and Gawienowski and Chatterjee, 1980). Their studies have demonstrated that $\mathrm{GA}_{3}$ is estrogenic, androgenic and acts synergistically with estradiol, in rats; $\mathrm{GA}_{3}$ elicited an estrogen like response in uteri of ovarictomized females and kept them in continuous estrus. Moreover, results of an estrogenic bioassay on one-day female chicks revealed that gibberellic acid mimics estradiol effect on oviduct length after 7 and 14 days injections with the dosage 100 and $200 \mu \mathrm{g}$ of $\mathrm{GA}_{3}$, which had the biological effects of 3 and $20 \mu \mathrm{g}$ of Estradiol after 7 days injections, and of 10 and $33 \mu \mathrm{g}$ of Estradiol after 14 days injections, respectively (Elkomy et al., 2007). As well, gibberellic acid mimics testosterone effect on comb's relative weight of male chicks after 7 days injections, with the experimental dosage 100 and $200 \mu \mathrm{g}$ of Gibberellic acid, which reaches the biological effect of 34 and $46 \mu \mathrm{g}$ of Testosterone after 7 injections (Elkomy et al., 2007).

The aim of the present study was to evaluate Gibberrelic acid estroidogenic effects on aging hens.

\section{MATERIALS AND METHODS}

This study was conducted at the Poultry Research center, Faculty of Agriculture, Alexandria University, during the year of 2008. A total of 100 hens at the end of egg production curve (64 weeks of age) from Alexandria strain were used in this study. Birds were fed diet that contained $2745 \mathrm{kcal} / \mathrm{kg} \mathrm{ME}$ 
and $16.2 \%$ crude protein. Feed and water were provided ad libtum throughout the experimental period. Birds were randomly assigned to 5 treatments of 2 replicates each (10 birds each). Groups 2 and 3 were injected subcutaneously with $0.2 \mathrm{ml}$ of solution containing different levels of $\mathrm{GA}_{3}(200,400 \mu \mathrm{g}$ $\mathrm{GA}_{3} / \mathrm{kg}$ body weight/week) while, groups 4 and 5 were injected with the same solution which contains estradiol 17- $\beta$ (100 and 200 $\mu \mathrm{g} E_{2} / \mathrm{kg}$ body weight/week), whereas, group 1 served as a control group which injected with the injection solution (ethanol-sesame oil mixture 1:11) during the first 4 weeks of the experimental period (TRT), After the 4 weeks treatment period, groups were kept without treatment for 4 weeks as a recovery period (REC)).

Egg production (egg/hen/week) and egg weight $(\mathrm{g})$ were recorded for each replicate in each treatment group. Blood samples were withdrawn from the brachial vein from five females (randomly chosen) from each treatment group to obtain plasma or serum, blood samples were collected at $8 \mathrm{Am}$ from hen that already laid its egg to obtain blood samples at the same stage of egg production cycle. Plasma or serum was stored at $-20{ }^{\circ} \mathrm{C}$ for later analysis. Serum total protein (STP) concentration as $(\mathrm{g} / \mathrm{dl})$ was measured by the Biuret method as described by Armstrong and Carr (1964). Total cholesterol (TCh) concentration as $(\mathrm{mg} / \mathrm{dl})$ was determined according to Bogin and Keller (1987). Plasma glucose (PG) concentration as $(\mathrm{mg} / \mathrm{dl})$ was estimated according to the method of Trinder (1969). Serum calcium (SCa) concentration as (mg/dl) was measured according to the method of Tietz (1986).

Radioimmunoassay (RIA) was used for FSH, LH and E2 determinations (Krishan et al., 1993; Follett et al., 1972 and Akiba et al., 1982)

\section{Statistical analysis:}

Data were analyzed by analysis of variance using the general linear model procedure (Proc GLM; SAS institute, 1996). For the overall means, data was classified according to 5 treatments and the mean of each treatment was used. Differences among means were determined using Duncan test (Duncan, 1955).

\section{RESULTS AND DISCUSSION}

\section{Estroidogenic effect of Gibberrellic acid on Gonadotrophins profil ( $\mathrm{LH}$ and FSH):}

Overall, low and high $\mathrm{E}_{2}$ treatments resulted in a 340 and $240 \%$ increase, respectively $(P=0.0001)$ in $\mathrm{LH}$ concentrations $(27.3 \pm 3.4$ and $21.1 \pm 4.6 \mathrm{ng} / \mathrm{ml})$ compared to control $(6.2 \pm 0.12 \mathrm{ng} / \mathrm{ml})$ whereas, low and high $\mathrm{GA}_{3}$ treatments resulted in a 125 and $185 \%$ increase, respectively $(P=0.0001)$ (Table 1). As expected, LH in control birds did not differ between TRT and REC periods. Low- $\mathrm{E}_{2}$ boosted LH during the TRT period to $444 \%$ higher than control and it remained $236 \%$ higher during the REC period $(P=0.0001)$ (Table 1). The effect of high- $\mathrm{E}_{2}$ was less profound during the TRT period but more profound during REC period, with increases of $67 \%$ and $432 \%$ over control during the TRT and REC periods, respectively. On the other hand, low- $\mathrm{GA}_{3}$ boosted LH during the TRT period to $33 \%$ higher than control and it remained $20 \%$ higher during the REC period $(P=0.0001)$ (Table 1). The effect of high-GA was more profound, with increases of $91 \%$ and $293 \%$ over control during the TRT and REC periods, respectively (Table 1).

Regarding FSH concentrations, the values shown in Table (1) represent increases ( $p=0.0001$ ) over control of $400 \%$ and $427 \%$ for low- and high- $\mathrm{E}_{2}$, respectively. Low and high $\mathrm{GA}_{3}$ treatments resulted in a 27 and $80 \%$ increase, respectively $(P=0.0001)$ (Table 1). Low- $\mathrm{E}_{2}$ dose stimulated FSH secretion to be $1050 \%$ over control during TRT but this effect was reduced during REC to reach $164 \%$, and the response to high- $\mathrm{E}_{2}$ dose compared to control were increased FSH secretion to reach $338 \%$ and $464 \%$ during TRT and REC, respectively. On the other hand, low- $\mathrm{GA}_{3}$ boosted FSH during the TRT period to $137 \%$ higher than control group and it didn't differ than control during the REC period $(P=0.0001)$ (Table 1). The effect of high-GA $\mathrm{G}_{3}$ was more profound, with increases of $137 \%$ and $59 \%$ over control during the TRT and REC periods, respectively (Table 1).

The increasing effect of $\mathrm{E}_{2}$ treatment on $\mathrm{LH}$ and FSH levels can be explained by the findings of Dunn et al. (1996) who suggested that the decrease in ovarian function in old laying hens could be mediated by a reduction in GnRH mRNA transcription and/or stability. Moreover, the discovery of a putative avian gonadotrophin inhibitory hormone $\mathrm{GnIH}$, (Tsutsui et al., 2000) presented a new possibility that reduced plasma $\mathrm{LH}$ in aging laying hens could be a consequence of increased $\mathrm{GnIH}$ release. This view is strengthened by the observation that increased GnIH mRNA is associated with depressed plasma LH in incubating hens (Ciccone et al., 2004). On the other hand Estradiol or a combination of Estradiol and progesterone treatment caused a significant decrease in pituitary GnIHR mRNA quantity suggesting that GnIHR gene expression is possibly down regulated in response to a surge in circulating 
estradiol (Maddineni et al., 2008). Present findings also prove $\mathrm{GA}_{3}$ estrogenic effect in old hens with $\mathrm{GA}_{3}$ treatments boosting $\mathrm{LH}$ and FSH levels (as estradiol treatments did) in a dose dependent manner.

\section{Estroidogenic effect of Gibberrellic acid on Estradiol hormone secretion:}

As expected with estradiol treatment, low$\mathrm{E}_{2}$ resulted in a $50 \%(p=0.0002)$ increase in blood $\mathrm{E}_{2}$ profiel compared to control hens, as indicated by the values shown in Table 1 . Meanwhile, The response to high- $\mathrm{E}_{2}$ did not differ from control. On the other hand, Gibberillic acid treatment resulted in a 13 and $50 \%$ increase $(p=0.0002)$ in blood $\mathrm{E}_{2}$ profiel compared to control with the low and high doses, respectively (Table 1).

Concentrations of blood $\mathrm{E}_{2}$ in control hens did not change over the course of the experiment. Low- $\mathrm{E}_{2}$ treatment resulted in elevation of blood $\mathrm{E}_{2}$ over control by 83 during TRT and it didn't differ than control during the REC period $(p=0.0009)$. The response of blood $\mathrm{E}_{2}$ to high- $\mathrm{E}_{2}$ treatment differed considerably, wheras, blood $\mathrm{E}_{2}$ was decreased significantly during TRT but it was did not diffee during REC periods compared to control group. On the other hand, low- $\mathrm{GA}_{3}$ resulted in a non significant (14 and $12 \%$ ) increase over control during the TRT and REC periods, respectively. The response of blood $\mathrm{E}_{2}$ to high$\mathrm{GA}_{3}$ did not differ than control during the TRT period but it increased by $66 \%$ during the recovery period ( $p=0.0009)$ (Table 1$)$.

These findings are in harmony with previous findings, when Japanese quail hens were injected with estradiol, serum estradiol concentration was higher in the injected group than in the control group (Samar and AbdElhady, 2009). Present findings also prove the $\mathrm{GA}_{3}$ estrogenic effect in old hens with $\mathrm{GA}_{3}$ treatments and come in agreement with Elkomy et al. (2007) findings, who stated that $\mathrm{GA}_{3}$ not only mimics estradiol biological effect but also have effects similar to those of estrogen with a suggestion that $\mathrm{GA}_{3}$ can also stimulate estrogen secretion Elkomy et al. (2008).

\section{Estroidogenic effect of Gibberrellic acid on Egg Production:}

Overall,egg production increased $(P=0.0001)$ as a result of low- and high- $\mathrm{E}_{2}$ treatments by $19 \%$ and $9 \%$, respectively, over control (Table 1). Whereas, it decreased by $9 \%$ with low- $\mathrm{GA}_{3}$ and didn't differ than control with the high- $\mathrm{GA}_{3}$.

On the other hand, egg weight responded differently to treated pulletes with $E_{2}$ as it declined $(P=0.0001)$ to $98 \%$ of control egg weight with the low- $\mathrm{E}_{2}$ treatment, but did not differ than control with the high- $\mathrm{E}_{2}$ treatment (Table 1). Low and high-GA $\mathrm{A}_{3}$ doses decreased egg weight to $99 \%$ and $97 \%$ of control egg weight.

Overall, low- and high- $\mathrm{E}_{2}$ treatments resulted in a $10 \%$ and $4 \%$ increase, respectively $(P=0.0001)$ in egg mass compared to control (Table 1). Whereas, it decreased by $6.5 \%$ with low- $\mathrm{GA}_{3}$ but increased by $6 \%$ with the high- $\mathrm{GA}_{3}$ treatment compared to control group.

These findings are consistant with those of El-Afifi and Abu Table (2002); Hamdy et al. (2002); Elghalid (2005); and Samar and AbdElhady (2009). Who reported that egg number and egg mass were significantly improved when Leghorn pullets and immature quail females were treated with estradiol. High-GA apparently exerts effects on egg production traits similar to high dose of estradiol effects.

\section{Estroidogenic effect of Gibberrellic acid on Blood profile:}

Neither $E_{2}$ nor $G_{3}$ doses affected blood cholesterol level. Low and high $\mathrm{E}_{2}$ doses resulted in 3 and $11 \%$ in cholesterol concentrations respectively $(P=0.2858)$, whereas, increasing blood cholesterol concentration was found with low $\mathrm{GA}_{3}$ treatment only, which resulted in a $8 \%$ increase compared with control group $(P=0.2858)$ (Table 2).

Regarding plasma triglycerides concentrtation, the values shown in Table (1) represented non significant increases $(P=0.4428)$ over control of $4 \%$ for low- and high- $\mathrm{E}_{2}$ treatments. Meanwhile, Low and high $\mathrm{GA}_{3}$ treatments didn't differ from control $(P=0.4428)$ (Table 2).

Blood calcium concentration showed significant increases $(P=0.0001)$ due to low and high- $\mathrm{E}_{2}$ treatments by 17 and $14 \%$ over control, respectively. Gibberrelic acid $\left(\mathrm{GA}_{3}\right)$ treatments showed the same trend as $E_{2}$ treatments. Blood calcium concentration increased by 14 and $13 \%$ over control group due to treated aging hens with low and high$\mathrm{GA}_{3}$ doses, respectively $(P=0.0001)$ (Table 2$)$.

Plasma glucose levels didn't change with the low- $\mathrm{E}_{2}$ treatment while it decreased by 2.6 , 7.7 and $2.2 \%$ compared to control with the high- $\mathrm{E}_{2}$, low-GA $\mathrm{G}_{3}$ and high-GA $\mathrm{G}_{3}$, respectively and this decreas wa significant with low- $\mathrm{GA}_{3}$ only $(P=0.002)$ (Table 2$)$.

Serum total protein increased $(P=0.0001)$ as a result of either $\mathrm{E}_{2}$ or $\mathrm{GA}_{3}$ treatments, where, it increased to reach 107 and $114 \%$ of control with the low and high- $\mathrm{E}_{2}$ treatments, respectively and to reach 106 and $122 \%$ of 
control with the low and high-GA $\mathrm{G}_{3}$ treatments, respectively (Table 2).

Results obtained due to $E_{2}$ treatment are in agreement with previous findings regarding $E_{2}$ effects on blood profile. Increases in plasma lipids can be attributed to the fact that estradiol activates lipids metabolism during vitellogensis (Walzem, 1996) and Johnson (1986) who reported that laying hens with $E_{2}$ short-term administration had significantly higher plasma total lipids. Blood calcium increases can be attributed to estrogen increasing total blood calcium, primarily by stimulating the production of blood-calcium binding proteins (Bacon et al., 1980). Glucose reduction was also reported by Samar and Abd-Elhady (2009) when immature quails were treated with estradiol.

It can be concluded that gibberrelic acid exerts the same effects on aged hens which are similer to estrogen effects mimicing its actions on egg production traits and blood profile. Moreover, estrogen hormone levels suggest that gibberrilc acid can also stimulate estrogen secration.

\section{REFERENCES}

Abdel-Hamid, A.M., T.M. Dorra, M.A. Ali and H. Abou-Egla, 1994. Effect of Gibberellic Acid on broiler chickens performance and some Metabolic Parameters. Archive of Animal Nutrition, 40, 269-276.

Akiba Y, L.S. Jensen, C.R. Bart, R.R. Kraeling, 1982. Plasma estradiol, thyroid hormones and liver lipids content in laying hens fed different caloric diets. J. Nutr., 112, 299-308.

Anderson, D.L., R.D. Witkowsky and A.M. Gawienowski, 1982. effect of Gibberellic acid on production characteristics of aged and force molted chickens in cages. Poult Scie, 61(8), 1660-1666.

Armstrong, W.D. and C.W. Carr, 1964. Physiological Chemistry Laboratory Direction, 3rd ed. Burges Publishing, Minneololis, MN, USA.

Azza El-Sebai, M. Abaza and Samar A. Elnagar, 2003. Physiological effects of Bibberellic acid (GA3) on female Japanese quail production and performance. Egyp.Poult.Sci.J., 23, IV, 977-991.

Bacon, W.L., K.I. Brown and M.A. Musser, 1980. Changes in plasma calcium, phosphorius, lipids, and estrogens in turkey hens with reproductive status. Poult Scie, 59, 444.

Baydar, I., 2002. Effect of Gibberellic acid treatment for pollen sterility induction on the physiological activity and endogenous hormone levels of the seed of sunflower. Tur. J. Biol,. 26, 235-239.

Bogin, E. and P. Keller, 1987. Application of clinical biochemistry-try to medically relevant animal models and standardization and quality control in animal biochemistry. Journal of Clinical Chemistry and Biochemistry, 25, 873-878.

Celik, I., M. Turker and Y. Tuluce, 2007. Abcisic acid and gibberellic acid cause increased lipid peroxidation and fluctuated antioxidant defense systems of various tissues in rats. J Hazard Mater, 148(3), 6239.

Ciccone N.A., I.C. Dunn, T. Boswell, K. Tsutsui, T. Ubuka, K. Ukena and P.J. Sharp, 2004. Gonadotrophin inhibitory hormone depressesgonadotrophin and FSH_ subunit expression in the pituitary of the domestic chicken. J. Neuroendocrinol, 16, 999-1006.

Duncan, D.B., 1955. Multiple range and multiple F tests. Biometrics, 11, 1-42.

Dunn I.C., K.K. Beattie, D. Maney, H.M. Sang, R.T. Talbot, P.W. Wilson and P.J. Sharp, 1996. Regulation of chicken gonadotropin-releasing hormone-I mRNA in incubating, nest-deprived and laying bantam hens. Neuroendocrinology, 63, 504-513.

El-Afifi, S.H.F. and A.M. Abu Taleb, 2002. Calcium absorption and deposition in old egg-laying Japanese quail as affected by dietary supplementation with estradiol and cholicalciferol. Egypt. Poult. Sci. J., 22, 855-868.

Elghalid, O.A.H., 2005. Estraiol effects on blood profile and performance of Japanese quail at different stages of production. Ph.D. Thesis, Poultry Production Dep. Faculty of Agriculture, Alexandria Univ.

Elkomy, A.E.A., 2003. Physiological studies on Gibberellic acid (GA3) and reproductive functions of adult fowl. Ph.D. thesis. Faculty of Agriculture, Alexandria University, egypt.

Elkomy, A.E.A., Samar A. Elnagar and Azza El-Sebai, 2007. Steroidogenic effects of Gibberellic Acid (GA3) on chicks. Egypt. Poult. Scie.J., 27(IV), 1239-1255.

Elkomy A.E.A., G. El-Shaarrawi, E. El-Ansary and A.A. Elnagar, 2008. Evaluation Of Estrogenic Response To Subcutaneously Injection Of Gibberellic Acid $\left(\mathrm{GA}_{3}\right)$ In Aged Female Fowl. Egypt. Poult. Sci.J., Vol. 28 (4), 2008.

Follett B.K., C.G. Scanes and F.J. Cunningham, 1972. A radioimmunoassay for avian luteinizing hormone. Endocrinol., 52, 359-378. 
Gawienowski, A.M., and V. Chatterjee, 1980. Effect of prostaglandin inhibitor on the uterotrophic response of Estradiol and Gibberellic acid . Life Sci., 20, 785-788.

Gawienowski, A.M., S.S., Stadnicki and M. Stacewicz-Sapuntzakis, 1977. Androgenic properties of gibberellic acid in the chick comb bioassay. Experientia, 33(11),15441545.

Hamdy, A.M.M., N.M. Esa, and A.A. Bakir, 2002. Prediction of egg production by some body measurements and plasma steroids hormones. Egypt. Poult. Sci. J., 22, 205218.

Johnson, A.L., 1986. Reproduction in the female.Chapter 18. In: Avian physiology P.D. Sturkie, Ed.New York: SpringerVerlag.

Krishnan K.A., J.A. Proudman, D.J. Blot and J.M. Bolir, 1993. Development of an homologous radioimmunoassay for chicken follicle stimulating hormone and measurement of plasma FSH during the ovulatory cycle. Comp. Physiol. 105A, 729-734.

Maddineni, S., O. Ocón-Grove, S.M. MKrzysik-Walker; G.L. Hendricks; J.A. Proudman and R. Ramachandran, 2008. Gonadotrophin-inhibitory hormone receptor expression in the chicken pituitary gland: potential influence of sexual maturation and ovarian steroids. J. Neuroendocrinol, 20(9), 1078-1088.

Riley, J.M. 1987. Gibberellic acid for fruit set and seed germination. CRFG Journal, 19, 10-12.

Samar A. Elnagar, and A.M. Abd-Elhady 2009. Exogenous Estradiol: Productive and reproductive performance and physiological profile of Japanese quail hens. International J. of Poult Scie., 8 (7), 634-641.

SAS Institute, 1996. SAS ${ }^{\circledR}$ User's Guide: Statistics. SAS Institute Inc., Cary,NC.

Tietz, N.W. 1986. Fundamentals of Clinical Chemistry. WBSaunders Company, Philadelphia, p. 723.

Trinder, P., 1969. Colorimetric method for the determination of blood glucose. Annals of Clinical Biochemistry, 6, 24.

Tsutsui, K., Saigoh E., Ukena K., T H. eranishi, Y. Fujisawa, M. Kikuchi, S. Ishii and P.J. Sharp, 2000. A novel avian hypothalamic peptide inhibiting gonadotropin release. Biochem. Biophys. Res. Commun, 275, 661-667.

Walzem, R.L., 1996. Lipoproteins and the laying hen: form follows function. Poult. and Avian Biology Reviews, 7, 31-64.

Table 1. Mean $( \pm$ S.E.) of reproductive status parameters of old hens treated with different levels of Estradiol ( E2) or Gebberellic acid $\left(\mathrm{GA}_{3}\right)$ during one month of treatment (TRT) and one month of recovery (REC)

\begin{tabular}{|c|c|c|c|c|c|c|c|}
\hline & & $\begin{array}{c}\mathbf{L H} \\
(\mathbf{n g} / \mathbf{m l})\end{array}$ & $\begin{array}{c}\text { FSH } \\
(\mathrm{ng} / \mathrm{ml})\end{array}$ & $\begin{array}{c}\mathrm{E} 2 \\
(\mathrm{pg} / \mathrm{ml})\end{array}$ & $\begin{array}{c}\text { Egg } \\
\text { number } \\
\text { (hen/week) }\end{array}$ & $\begin{array}{c}\text { Egg weight } \\
\text { (g) }\end{array}$ & $\begin{array}{l}\text { Egg mass } \\
(\text { g) }\end{array}$ \\
\hline Control & & $6.2 \pm 0.12^{E}$ & $1.5 \pm 0.3^{C}$ & $355 \pm 18^{B}$ & $4.02 \pm 0.22^{\mathrm{C}}$ & $56.58 \pm 0.28^{\mathbf{A}}$ & $276 \pm 11^{C}$ \\
\hline E2 (100) & & $27.3 \pm 3.4^{\mathbf{A}}$ & $7.5 \pm 0.7^{\mathbf{A}}$ & $533 \pm 41^{\mathbf{A}}$ & $4.78 \pm 0.21^{\mathbf{A}}$ & $\begin{array}{c}55.73 \pm \\
0.21^{\mathbf{B}}\end{array}$ & $304 \pm 9.8^{\mathbf{A}}$ \\
\hline E2 (200) & & $21.1 \pm 4.6^{\mathbf{B}}$ & $7.9 \pm 0.9^{\mathbf{A}}$ & $340 \pm 32^{\mathbf{B}}$ & $\begin{array}{l}4.38 \pm \\
0.21^{\mathbf{B}}\end{array}$ & $56.55 \pm 0.23^{\mathbf{A}}$ & $287 \pm 10^{\mathrm{BC}}$ \\
\hline $\mathrm{GA}_{3}(200)$ & & $7.8 \pm 0.5^{\mathbf{D}}$ & $1.9 \pm 0.1^{\mathrm{C}}$ & $402 \pm 26^{\mathbf{B}}$ & $3.67 \pm 0.22^{\mathrm{D}}$ & $\begin{array}{c}55.76 \pm \\
0.24^{\mathbf{B}}\end{array}$ & $258 \pm 11^{\mathrm{D}}$ \\
\hline $\mathrm{GA}_{3}(400)$ & & $17.7 \pm 1.5^{\mathrm{C}}$ & $2.7 \pm 0.4^{\mathbf{B}}$ & $531 \pm 38^{\mathbf{A}}$ & $4.04 \pm 0.23^{\mathrm{C}}$ & $54.77 \pm 0.26^{\mathrm{C}}$ & $292 \pm 10^{\mathbf{A B}}$ \\
\hline $\mathrm{P}$ value & & 0.0001 & 0.0001 & 0.0002 & 0.0001 & 0.0001 & 0.0001 \\
\hline \multirow{2}{*}{ Control } & TRT & $6.4 \pm 0.06^{\mathbf{G}}$ & $0.8 \pm 0.05^{\mathbf{F}}$ & $351 \pm 31^{\mathrm{BC}}$ & $4.28 \pm 0.31$ & $56.35 \pm 0.41$ & $277 \pm 16$ \\
\hline & REC & $5.9 \pm 0.05^{\mathbf{G}}$ & $2.2 \pm 0.11^{\mathbf{E}}$ & $360 \pm 26^{\mathrm{BC}}$ & $3.76 \pm 0.32$ & $56.78 \pm 0.37$ & $275 \pm 16$ \\
\hline \multirow{2}{*}{ E2 (100) } & TRT & $34.8 \pm 0.41^{\mathrm{A}}$ & $9.2 \pm 0.17^{\mathbf{B}}$ & $643 \pm 42^{\mathbf{A}}$ & $4.86 \pm 0.29$ & $55.28 \pm 0.33$ & $296 \pm 14$ \\
\hline & REC & $19.8 \pm 0.11^{\mathbf{D}}$ & $5.8 \pm 0.41^{\mathrm{C}}$ & $423 \pm 21^{\mathbf{B}}$ & $4.70 \pm 0.31$ & $56.19 \pm 0.23$ & $313 \pm 13$ \\
\hline \multirow{2}{*}{ E2 (200) } & TRT & $10.71 .01^{\mathrm{E}}$ & $3.5 \pm 0.66^{\mathbf{D}}$ & $248 \pm 21^{\mathrm{C}}$ & $4.50 \pm 0.29$ & $56.28 \pm 0.34$ & $285 \pm 14$ \\
\hline & REC & $31.4 \pm 0.23^{\mathbf{B}}$ & $12.4 \pm 0.23^{\mathrm{A}}$ & $431 \pm 4.4^{\mathbf{B}}$ & $4.26 \pm 0.31$ & $56.74 \pm 0.29$ & $290 \pm 15$ \\
\hline \multirow{2}{*}{$\mathrm{GA}_{3}(200)$} & TRT & $8.5 \pm 0.49^{F}$ & $1.9 \pm 0.07^{\mathbf{E}}$ & $401 \pm 37^{\mathbf{B}}$ & $3.86 \pm 0.31$ & $55.97 \pm 0.36$ & $257 \pm 16$ \\
\hline & REC & $7.1 \pm 0.72^{\mathrm{FG}}$ & $1.9 \pm 0.12^{\mathbf{E}}$ & $403 \pm 18^{\mathbf{B}}$ & $3.48 \pm 0.31$ & $55.41 \pm 0.31$ & $259 \pm 16$ \\
\hline \multirow{2}{*}{$\mathrm{GA}_{3}(400)$} & TRT & $12.2 \pm 0.12^{\mathrm{E}}$ & $1.9 \pm 0.11^{\mathbf{E}}$ & $466 \pm 39^{\mathbf{B}}$ & $4.33 \pm 0.31$ & $54.37 \pm 0.35$ & $295 \pm 13$ \\
\hline & REC & $23.2 \pm 0.58^{\mathrm{C}}$ & $3.5 \pm 0.13^{\mathbf{D}}$ & $596 \pm 27^{\mathbf{A}}$ & $3.75 \pm 0.33$ & $55.01 \pm 0.40$ & $288 \pm 15$ \\
\hline $\mathrm{P}$ value & & 0.0001 & 0.0001 & 0.0009 & 0.4716 & 0.2598 & 0.1723 \\
\hline
\end{tabular}


Table 2. Mean $( \pm$ S.E.) of reproductive status parameters of old hens treated with different levels of Estradiol (E2) or Gebberellic acid $\left(\mathrm{GA}_{3}\right)$ during one month of treatment (TRT) and one month of recovery $(\mathrm{REC})$

\begin{tabular}{|c|c|c|c|c|c|c|}
\hline & & $\begin{array}{c}\text { Cholesterol } \\
\text { (mg/dl) }\end{array}$ & $\begin{array}{c}\text { Triglycerides } \\
\text { (mg/dl) }\end{array}$ & $\begin{array}{l}\text { Calcium } \\
\text { (mg/dl) }\end{array}$ & $\begin{array}{l}\text { Glucose } \\
\text { (mg/dl) }\end{array}$ & $\begin{array}{c}\text { T. protein } \\
\text { (g/dl) }\end{array}$ \\
\hline Control & & $180 \pm 10$ & $389 \pm 6$ & $14.39 \pm 0.52^{B}$ & $271 \pm 5^{A}$ & $4.97 \pm 0.17^{\mathrm{C}}$ \\
\hline E2 (100) & & $185 \pm 9$ & $404 \pm 4$ & $16.77 \pm 0.53^{\mathbf{A}}$ & $276 \pm 6^{\mathbf{A}}$ & $5.32 \pm 0.12^{\mathbf{B C}}$ \\
\hline E2 (200) & & $200 \pm 8$ & $403 \pm 2$ & $16.40 \pm 0.56^{\mathbf{A}}$ & $264 \pm 4^{\mathrm{AB}}$ & $5.67 \pm 0.17^{\mathbf{B}}$ \\
\hline $\begin{array}{l}\mathrm{GA}_{3} \\
(200)\end{array}$ & & $195 \pm 13$ & $377 \pm 9$ & $16.38 \pm 0.52^{\mathbf{A}}$ & $250 \pm 7^{\mathbf{B}}$ & $5.28 \pm 0.14^{\mathbf{B C}}$ \\
\hline $\mathrm{GA}_{3}(400)$ & & $179 \pm 12$ & $391 \pm 7$ & $16.19 \pm 0.79^{\mathbf{A}}$ & $265 \pm 7^{\mathbf{A B}}$ & $6.08 \pm 0.10^{\mathbf{A}}$ \\
\hline $\mathrm{P}$ value & & 0.2858 & 0.4428 & 0.0001 & 0.0002 & 0.0001 \\
\hline \multirow{2}{*}{ Control } & TRT & $166 \pm 16$ & $390 \pm 9$ & $12.7 \pm 0.65$ & $283 \pm 9$ & $4.70 \pm 0.26^{\mathrm{D}}$ \\
\hline & REC & $194 \pm 12$ & $388 \pm 9$ & $16.1 \pm 0.44$ & $258 \pm 4$ & $5.24 \pm 0.19^{\mathrm{CD}}$ \\
\hline \multirow{2}{*}{ E2 (100) } & TRT & $182 \pm 16$ & $397 \pm 8$ & $15.5 \pm 0.66$ & $288 \pm 7$ & $5.49 \pm 0.13^{\mathbf{B C}}$ \\
\hline & REC & $187 \pm 11$ & $410 \pm 1$ & $18.1 \pm 0.65$ & $264 \pm 7$ & $5.14 \pm 0.20^{\mathrm{CD}}$ \\
\hline \multirow{2}{*}{ E2 (200) } & TRT & $185 \pm 10$ & $405 \pm 1$ & $15.3 \pm 0.62$ & $267 \pm 4$ & $6.22 \pm 0.19^{\mathbf{A}}$ \\
\hline & REC & $215 \pm 11$ & $402 \pm 5$ & $17.5 \pm 0.84$ & $261 \pm 6$ & $5.13 \pm 0.16^{\mathrm{CD}}$ \\
\hline \multirow{2}{*}{$\mathrm{GA}_{3}(200)$} & TRT & $168 \pm 18$ & $381 \pm 12$ & $15.2 \pm 0.61$ & $271 \pm 4$ & $5.37 \pm 0.15^{\mathrm{C}}$ \\
\hline & REC & $222 \pm 9$ & $374 \pm 13$ & $17.5 \pm 0.71$ & $229 \pm 10$ & $5.20 \pm 0.23^{\mathrm{CD}}$ \\
\hline \multirow{2}{*}{$\mathrm{GA}_{3}(400)$} & TRT & $170 \pm 18$ & $382 \pm 11$ & $13.3 \pm 0.83$ & $284 \pm 5$ & $5.96 \pm 0.18^{\mathrm{AB}}$ \\
\hline & REC & $188 \pm 17$ & $399 \pm 7$ & $19.1 \pm 0.68$ & $247 \pm 10$ & $6.21 \pm 0.08^{\mathbf{A}}$ \\
\hline$P$ value & & 0.5599 & 0.6193 & 0.0594 & 0.1350 & 0.0004 \\
\hline
\end{tabular}

البيض التأثير الأستروجيني لحامض الجبريلليك (هرمون نباني) علي الاجاجات البياضة في نهاية مرحله أنتاج

علاء السيد الكومي', أسامة أحمد حسن ', سمر علي النجار '

ا ـ معطل بحوث زراعة الأراضي القاطلة، مدينة الأبحاث العلمية والتطبيقات التكنولوجية، r ـ قسم إنتاج الدواجن، كلية النزراعة، جامعة الأسكندرية

لقياس تأثير الفعل الأستروجيني لحامض الجبريلليك (هرمون نباتي) علي الدجاجات البياضة في نهاية مرحلة أنتاج البيض تم

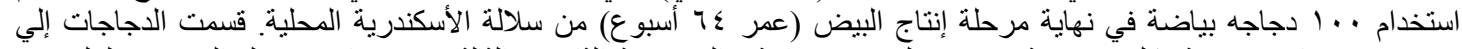

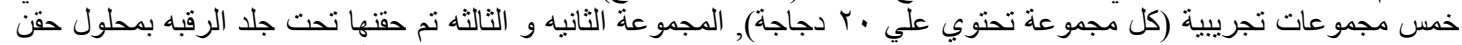

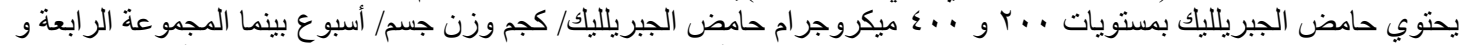

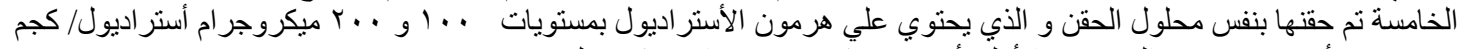

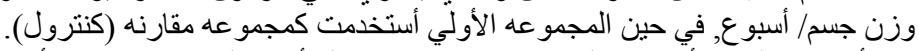

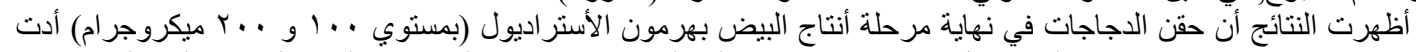

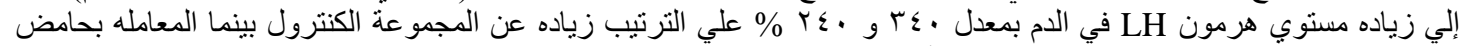

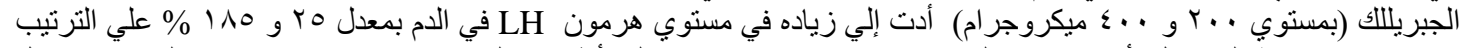

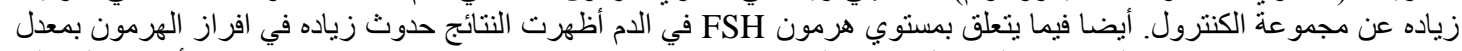

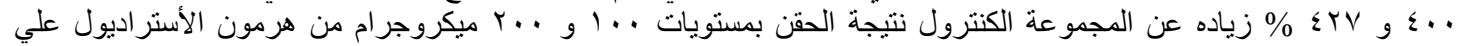

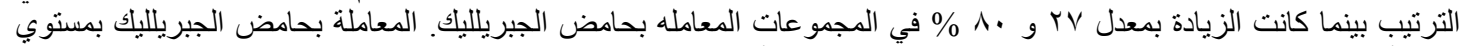

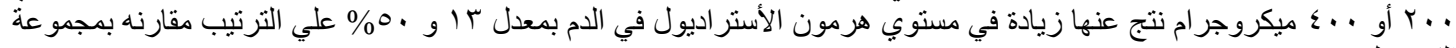
الكنترول. (- الك.

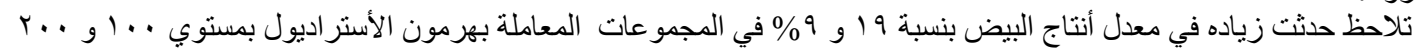

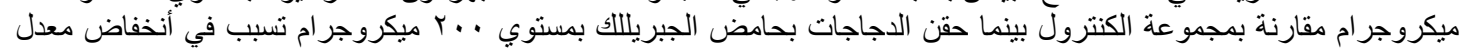

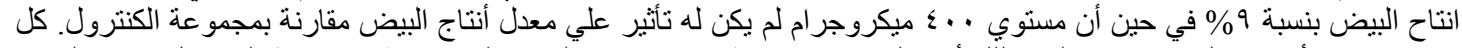

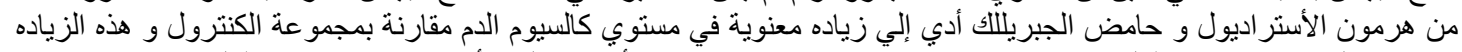

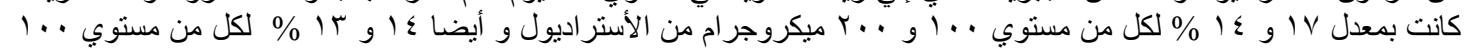

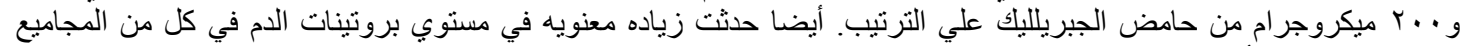

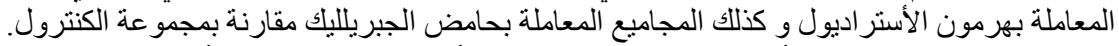

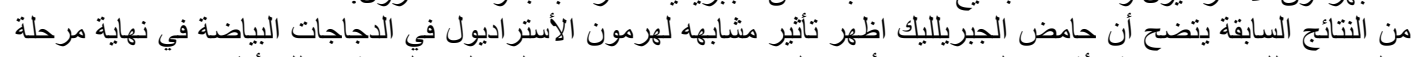

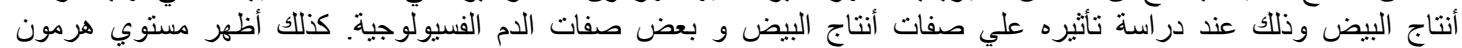

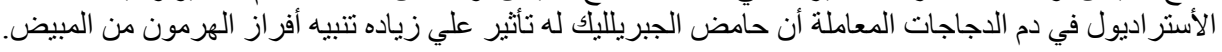

